\title{
A REVIEW ON PENTA HELIX ACTORS IN VILLAGE TOURISM DEVELOPMENT AND MANAGEMENT
}

\author{
Trisna Putra. \\ Universitas Negeri Padang. Indonesia. \\ tputra@fpp.unp.ac.id
}

\begin{abstract}
The popularity of village tourism, as a possibility to spend the vacation, has increased in Indonesia. However, there is still a limited number of the village being managed as a product and applied for village tourism program successfully. The Penta Helix of Government-Community-Business-Academics-Social Entrepreneur is a combination of stakeholder in developing tourism destination. This study applies the content analysis methodology by reviewing seven current journal articles related to village tourism development in Indonesia. This study reviews an extensive literature on village tourism study using the institutional database. This study aims to identify the stakeholders involved in village tourism development. Furthermore, this study assessed the actor's specific roles in village tourism development. The result of the study showed that not all tourism stakeholders as proposed by the Penta helix model play significant roles in village tourism development. Most of the study on village tourism did not pay attention to the role of academician and social entrepreneur, as the community, government and business were much preferred.
\end{abstract}

Keywords: village tourism, cross-sector collaboration, stakeholders, Penta helix model

\section{INTRODUCTION}

As an archipelagic country, Indonesia has abundance potencies of nature and culture. They are spread through thousands of island and lay characteristically in every area of Indonesia. The ultimate in diversity as Indonesia well known last decade make it is potentially visited by thousands of culture and natural wonders. The genuine of them can be found almost in all villages. Based on Indonesia Statistical Yearbook of 2018 there were 83.344 villages throughout Indonesia. Those villages have potencies to be developed as tourism product with the implementation of the village tourism program. As stated on the regulation of the Minister of Tourism number PM.26/UM.001/MKP/2010 on general guideline of national program on tourism community empowerment trough village tourism states that tourism village offers a whole atmosphere reflects the countryside authenticity, either layout, the architecture of the building, as well as the pattern of 
the social and cultural life of society, customs of everyday life. Besides that it is able to provide components of the basic needs of travelers, such as accommodation, food and drinks, souvenirs and tourist attractions. The ideal tourist village is a live of villager manages by them to improve the economy as well as to the prosperity of the village. Since its development is density, therefore collaboration and assistance from other stakeholders are considered important. In order to empower the villager, the stakeholders may have working in three alternatives treatment (Prayogi, 2011) they are; education, informal training, and the involvement in tourism management.

According to the Central Bureau of Statistic (BPS) reported on merdeka.com, there are 1.734 develop into a tourism village. Dominantly those villages exist in Java and Bali with 857 villages, Sumatera 355 villages, Nusa Tenggara 189 Villages, Sulawesi 119 villages, Kalimantan 117 villages, Papua 74 villages, and Maluku 23 villages. However, there still many other potential villages scattered throughout the country are now facing various economic and social problems. The government of Indonesia proposed tourism village as one of the solutions to combat the economic and social issues. This program in line with Petrevska \& Dimitrov (2013) consideration that economic growth and land use planning will be affected by the development of tourism. The concept of village tourism has a critical consideration on the empowerment of local people as well as encouraging conservation of natural resource, social and local culture.

As a destination, those villages will engage with several stakeholders both with direct and indirect contribution. Destination consists of a group of actors connected by mutual relationships and binds with specific rules, where the action of each actor influences those of the others. Therefore the common vision and mission must be defined and attained in a coordinated way (Manente and Minghetti, 2006). However, in reality, this agreement can't be on track since the unproductive contribution of its stakeholders. According to Gardiner (2005) stakeholders have actively involved may be positively or negatively affected by. Thus, studies have revealed that stakeholders can contribute to project success or failure (Newcombe, 2003).

Penta helix is one of the concepts of the cross-sector collaboration of stakeholders that rally round the development of village tourism. The Penta helix model is a conceptual framework of the collaboration between community, government, business, academics, and social entrepreneur. Penta helix models developed by Bjork (2014) and Calzada (2016) shows the dynamic and complex relationships among the actors and emphasizes the flexible connection between the citizens or social entrepreneurs with all of the other actors. Five actors include public and private sectors, academia, civil society, and social entrepreneurs. In the existing literature, the relationship between the helixes and respective impacts on tourism village development does not appear clear.

This study aims to identify the actors involved in village tourism development. Furthermore, it assessed the actor's specific roles in village tourism development. This study adopted the Penta helix model in examining the stakeholder roles in village tourism development. In order to bring about well manage village tourism, cross-sector collaboration among different actors is required. 


\section{METHODOLOGY}

The research design was considered an extensive literature review on tourism village using the institutional database to search for recommended journals. Journals were searched using keywords such as "tourism village", "development"," stakeholder," and "Indonesia". Suitable articles were no older than 5 years. In the beginning, articles were chosen based on the analysis of title, keywords and abstract. These articles were studied in detail and selected them. Some articles were excluded due to inadequate geographic focus to the development of tourism village.

\section{RESULT AND DISCUSSION}

Based on the article reviews, seven articles had been selected and analyzed by extracting vital information such as the authors, articles title and publication. All of the articles provided with village tourism cases in Indonesia. Stand on the Penta Helix model, information on the actors and their roles in village tourism development were critically analyzed. There are three cases from village tourism in Jogyakarta, two cases in Bandung, one case from Bali and another case from central Java. All cases showed the cross-sector collaboration among stakeholders existed in village tourism. However, not all actors in a helix play a significant role in the village. The community, government, and business become the main stakeholders and the center of discussion. These three stakeholders give a contribution to developing and managing the existence of village tourism.

Meanwhile, one case comes up with an academic involvement on Tanjungsari village in Kendal, central Java. The role of academic in this case is mentoring household fish processing as a local home industry and potentially to be a tourist's attraction. Another Stakeholder collaboration is a social entrepreneur with the community. The case of Lopati Village, Jogyakarta show the participation of business entrepreneur in village tourism activity. 
Table 1: Penta Helix Actors and Roles

\begin{tabular}{|c|c|c|c|c|c|c|}
\hline Author(s) & $\begin{array}{l}\text { Ye } \\
\text { ar }\end{array}$ & Publish & Title & $\begin{array}{l}\text { Penta } \\
\text { Helix }\end{array}$ & Actors & Roles \\
\hline \multirow[t]{5}{*}{$\begin{array}{l}\text { Maulana.Y. } \\
\text { and } \\
\text { M.F.Sitinja } \\
\text { k }\end{array}$} & \multirow[t]{5}{*}{$\begin{array}{l}201 \\
8\end{array}$} & \multirow[t]{5}{*}{$\begin{array}{l}\text { IOP Conference } \\
\text { Series: Earth and } \\
\text { Environmental } \\
\text { Science }\end{array}$} & \multirow[t]{5}{*}{$\begin{array}{l}\text { Developing performance } \\
\text { excellence guidance for rural } \\
\text { tourism (case study: Wangun } \\
\text { Lestari Village, Bandung, } \\
\text { West Java, Indonesia) }\end{array}$} & $\begin{array}{l}\text { Governme } \\
\text { nt }\end{array}$ & $\begin{array}{l}\text { Central Government } \\
\text { Provincial Government } \\
\text { Local Government } \\
\text { Village Headman } \\
\end{array}$ & $\begin{array}{l}\text { Funding } \\
\text { Funding } \\
\text { program Creating, planning implementing } \\
\text { and monitoring } \\
\text { Monitoring evaluation, and improvement } \\
\text { and an early managing and coordinating }\end{array}$ \\
\hline & & & & $\begin{array}{l}\text { Communit } \\
\text { y }\end{array}$ & $\begin{array}{l}\text { Neighborhoods } \\
\text { Association(RT/RW) } \\
\text { Villagers } \\
\text { Coffee Farmer } \\
\text { Community } \\
\end{array}$ & $\begin{array}{l}\text { Conducting weekly report regarding } \\
\text { village situation (verbally) } \\
\text { Strengthening their culture as high } \\
\text { solidarity and friendly villagers }\end{array}$ \\
\hline & & & & Business & $\begin{array}{l}\text { Travel Agency } \\
\text { Coffee Distributor }\end{array}$ & $\begin{array}{l}\text { Promoting } \\
\text { Promoting }\end{array}$ \\
\hline & & & & Academic & Researcher & $\begin{array}{l}\text { Researching on rural tourism } \\
\text { Training and giving workshop }\end{array}$ \\
\hline & & & & $\begin{array}{l}\text { Social } \\
\text { Entrepren } \\
\text { eur }\end{array}$ & Not mention & Not mention \\
\hline \multirow[t]{4}{*}{$\begin{array}{l}\text { Widodo.S } \\
\text { et all }\end{array}$} & \multirow[t]{4}{*}{$\begin{array}{l}201 \\
8\end{array}$} & \multirow[t]{4}{*}{$\begin{array}{l}\text { Journal of Social } \\
\text { Science Studies } \\
\text { ISSN 2329-9150 } \\
2018 \text {, Vol. 5, } \\
\text { No. } 1\end{array}$} & \multirow{4}{*}{$\begin{array}{l}\text { Community Participation in } \\
\text { the Implementation of } \\
\text { Constitutional Laws through } \\
\text { the Village Tourism } \\
\text { Development in Tanjungsari } \\
\text { County Rowosari Subdistrict } \\
\text { Kendal }\end{array}$} & $\begin{array}{l}\text { Governme } \\
\text { nt }\end{array}$ & $\begin{array}{l}\text { Ministry of Women } \\
\text { Empowerment } \\
\text { BAPEDA } \\
\text { Tourism Agency } \\
\text { Village Government } \\
\end{array}$ & $\begin{array}{l}\text { Providing Home industry program on fish } \\
\text { processing } \\
\text { Mentoring household fish processing } \\
\text { Legitimizing with Circulating Letter } \\
\text { Proposing and planning }\end{array}$ \\
\hline & & & & $\begin{array}{l}\text { Communit } \\
\mathrm{y}\end{array}$ & $\begin{array}{l}\text { POKDARWIS } \\
\text { (Tourism Care } \\
\text { Community) } \\
\text { BUMDES } \\
\text { Community of fish } \\
\text { processing }\end{array}$ & $\begin{array}{l}\text { Organize tourist village } \\
\text { Attraction of tourist village }\end{array}$ \\
\hline & & & & Business & Not mention & Not mention \\
\hline & & & & Academi & University of PGRI & Mentoring household fish processing \\
\hline
\end{tabular}




\begin{tabular}{|c|c|c|c|c|c|c|}
\hline & & & & $\begin{array}{l}\text { Social } \\
\text { Entrepren } \\
\text { eur }\end{array}$ & Not mention & Not mention \\
\hline \multirow[t]{5}{*}{$\begin{array}{l}\text { Amerta, } \\
\text { I.M.S }\end{array}$} & \multirow[t]{5}{*}{$\begin{array}{l}201 \\
7\end{array}$} & \multirow{5}{*}{$\begin{array}{l}\text { International } \\
\text { Journal of Social } \\
\text { Sciences and } \\
\text { Humanities Vol. } \\
1 \text { No. 2, August } \\
2017 \text {, pages: } 20 \text { - } \\
28\end{array}$} & \multirow[t]{5}{*}{$\begin{array}{l}\text { The Role of Tourism } \\
\text { Stakeholders at Jasri Tourism } \\
\text { Village Development, } \\
\text { Karangasem Regency }\end{array}$} & $\begin{array}{l}\text { Governme } \\
\text { nt }\end{array}$ & $\begin{array}{l}\text { Local Government } \\
\text { Department of culture } \\
\text { and tourism } \\
\text { Village administrative }\end{array}$ & $\begin{array}{l}\text { Legitimizing with regent decree } \\
\text { Conducting socialization and providing } \\
\text { with guidance } \\
\text { Giving assistance and promotion } \\
\text { activities }\end{array}$ \\
\hline & & & & $\begin{array}{l}\text { Communit } \\
\text { y }\end{array}$ & Village community & $\begin{array}{l}\text { Providing and supporting tourist facilities } \\
\text { Establishing and supporting tourism } \\
\text { institution } \\
\text { Providing introduction of village } \\
\text { potencies }\end{array}$ \\
\hline & & & & Business & $\begin{array}{l}\text { Investor or } \\
\text { Businessman }\end{array}$ & $\begin{array}{l}\text { Proposing idea of tourism development } \\
\text { Giving motivation } \\
\text { Investing in accommodation } \\
\text { Making a promotion } \\
\text { Establishing a new tourist attraction }\end{array}$ \\
\hline & & & & Academic & Not mention & Not mention \\
\hline & & & & $\begin{array}{l}\text { Social } \\
\text { Entrepren } \\
\text { eur }\end{array}$ & Not mention & Not mention \\
\hline \multirow[t]{4}{*}{ Arida et al } & \multirow[t]{4}{*}{$\begin{array}{l}201 \\
7\end{array}$} & \multirow{4}{*}{$\begin{array}{l}\text { IOP Conf. } \\
\text { Series: Earth and } \\
\text { Environmental } \\
\text { Science } 98 \\
\text { (2017) } 012044\end{array}$} & \multirow{4}{*}{$\begin{array}{l}\text { Development Planning of } \\
\text { Tourist Village Using } \\
\text { Participatory Mapping (Case } \\
\text { study: Mambal Village, } \\
\text { Badung Regency, Indonesia) }\end{array}$} & $\begin{array}{l}\text { Governme } \\
\mathrm{nt}\end{array}$ & Central Government & Providing funding and guidance \\
\hline & & & & $\begin{array}{l}\text { Communit } \\
\text { y }\end{array}$ & $\begin{array}{l}\text { Local people } \\
\text { Head of village } \\
\text { Hindu priest } \\
\text { Tourism community } \\
\text { (tourism care } \\
\text { community) }\end{array}$ & $\begin{array}{l}\text { Providing a homestay or inn } \\
\text { Providing local food } \\
\text { Planning for village facilities, activities } \\
\text { and attraction }\end{array}$ \\
\hline & & & & Business & Travel agent & $\begin{array}{l}\text { Offering assistance to create calendar of } \\
\text { events, and promotion. }\end{array}$ \\
\hline & & & & Academic & Not mention & Not mention \\
\hline
\end{tabular}




\begin{tabular}{|c|c|c|c|c|c|c|}
\hline & & & & $\begin{array}{l}\text { Social } \\
\text { Entrepren } \\
\text { eur }\end{array}$ & Not mention & Not mention \\
\hline \multirow[t]{5}{*}{$\begin{array}{l}\text { Prayudi et } \\
\text { al }\end{array}$} & \multirow[t]{5}{*}{$\begin{array}{l}201 \\
7\end{array}$} & \multirow[t]{5}{*}{$\begin{array}{l}\text { PEOPLE: } \\
\text { International } \\
\text { Journal of Social } \\
\text { Sciences } \\
\text { ISSN 2454-5899 }\end{array}$} & \multirow[t]{5}{*}{$\begin{array}{l}\text { Analyzing Challenges of } \\
\text { Developing Ecotourism } \\
\text { Village in Sleman, } \\
\text { Yogyakarta, Indonesia: a } \\
\text { Community Development } \\
\text { Approach }\end{array}$} & $\begin{array}{l}\text { Governme } \\
\text { nt }\end{array}$ & $\begin{array}{l}\text { Minister of village, } \\
\text { development and } \\
\text { transmigration } \\
\text { Head of Cultural and } \\
\text { Tourism Agency } \\
\end{array}$ & $\begin{array}{l}\text { Providing Funding } \\
\text { Setting up a regulation, coordination and } \\
\text { protection }\end{array}$ \\
\hline & & & & $\begin{array}{l}\text { Communit } \\
\text { y }\end{array}$ & Villagers & Organizing village with commitment \\
\hline & & & & Business & $\begin{array}{l}\text { Association of the } \\
\text { Indonesian Tours and } \\
\text { Travel Agencies } \\
\text { Association of } \\
\text { Indonesian Hotels } \\
\end{array}$ & $\begin{array}{l}\text { Mediating tourists demands, expanding } \\
\text { tourism marketing, improving human } \\
\text { resource capacity, raising local potentials, } \\
\text { and applying tourism business standards }\end{array}$ \\
\hline & & & & Academic & Not mention & Not mention \\
\hline & & & & $\begin{array}{l}\text { Social } \\
\text { Entrepren } \\
\text { eur }\end{array}$ & Not mention & Not mention \\
\hline \multirow[t]{4}{*}{ Muslim, A. } & \multirow[t]{4}{*}{$\begin{array}{l}201 \\
6\end{array}$} & \multirow{4}{*}{$\begin{array}{l}\text { MIMBAR, Vol. } \\
\text { 32, No. 2nd } \\
\text { (December, } \\
\text { 2016), pp.343- } \\
352\end{array}$} & \multirow[t]{4}{*}{$\begin{array}{lr}\text { Economic } & \text { Community } \\
\text { Empowerment } & \text { Through } \\
\text { Tourist Village Development }\end{array}$} & $\begin{array}{l}\text { Governme } \\
\text { nt }\end{array}$ & $\begin{array}{l}\text { Central Government } \\
\text { Regency Government } \\
\text { Village Government }\end{array}$ & $\begin{array}{l}\text { Distributing Funding } \\
\text { Making policy concerning economic } \\
\text { community empowerment } \\
\text { Building community welfare }\end{array}$ \\
\hline & & & & $\begin{array}{l}\text { Communit } \\
\text { y }\end{array}$ & $\begin{array}{l}\text { Youth Organization } \\
\text { (Karang Taruna) } \\
\text { Female Farmer Group } \\
\text { (KWT) } \\
\text { Kader Sehat ( Health } \\
\text { Cadre) } \\
\text { Hamlet family welfare } \\
\text { empowerment (PKK) } \\
\text { Villager self - helping } \\
\text { Institution (LKMD) }\end{array}$ & $\begin{array}{l}\text { Managing and taking action to construct as } \\
\text { well as establish a village tourism program }\end{array}$ \\
\hline & & & & Business & Company & Providing a CSR for infrastructures \\
\hline & & & & Academic & Not mention & Not mention \\
\hline
\end{tabular}




\begin{tabular}{|c|c|c|c|c|c|c|}
\hline & & & & $\begin{array}{l}\text { Social } \\
\text { Entrepren } \\
\text { eur }\end{array}$ & Not mention & Not mention \\
\hline \multirow[t]{5}{*}{$\begin{array}{l}\text { Vitasurya.V } \\
\text {.R }\end{array}$} & \multirow[t]{5}{*}{$\begin{array}{l}201 \\
6\end{array}$} & \multirow{5}{*}{$\begin{array}{l}\text { Procedia - Social } \\
\text { and Behavioral } \\
\text { Sciences }\end{array}$} & \multirow{5}{*}{$\begin{array}{l}\text { Local Wisdom for Sustainable } \\
\text { Development of Rural } \\
\text { Tourism, Case on Kalibiru } \\
\text { and Lopati Village, } \\
\text { Province of Daerah Istimewa } \\
\text { Yogyakarta }\end{array}$} & $\begin{array}{l}\text { Governme } \\
\mathrm{nt}\end{array}$ & Government & Providing regulatory and supervision \\
\hline & & & & $\begin{array}{l}\text { Communit } \\
\text { y }\end{array}$ & $\begin{array}{l}\text { Community forest } \\
\text { farmer groups } \\
\text { (KTHKm), Handicraft } \\
\text { household industry: } \\
\text { Culinary household } \\
\text { industry, Cultural } \\
\text { group. }\end{array}$ & $\begin{array}{l}\text { Providing some pack variation of } \\
\text { attractions, such as educational tours } \\
\text { Making simple household industry } \\
\text { accordingly as the types of owned } \\
\text { businesses } \\
\text { Developing infrastructure and facilities to } \\
\text { support educational craft } \\
\text { Taking part as a group of } \\
\text { keepers/"marshall" to preserve land of } \\
\text { "wawengkon" and keep it sustainable } \\
\text { Managing waste from tourism activities }\end{array}$ \\
\hline & & & & Business & Not mention & Not mention \\
\hline & & & & Academic & Not mention & Not mention \\
\hline & & & & $\begin{array}{l}\text { Social } \\
\text { Entrepren } \\
\text { eur }\end{array}$ & Not mention & Not mention \\
\hline
\end{tabular}

Source: Content Analysis on December 2018 
Community

Generally, community represents a group of people interact with one another within a bounded geographic territory and share common norms, values, beliefs, behaviors or identity. Communities often share a sense of place that is situated in a given geographical area such as village. Base on the study, all of the researchers agree that the community of a village plays a significant role in developing and manage village tourism. Not only as managing their village, but the community is also the main attraction of tourists. Village living as well as a natural atmosphere that is unique and cannot be found in urban areas is the benefit of the village tourism program. Simply saying, the success of the development of sustainable tourism in the village lies in the empowerment of local community as an actor in building, owning and managing direct tourist facilities and services (Suarthana, et al., 2015).

Community being discussed comprise of individual, group of people and independent village administrative. The village administrative consists of Head of village (Kepala Desa), neighborhood association (RT/RW), Hamlet Family Welfare Empowerment (PKK), Village Self-Helping Institution (LKMD) Youth Organisation (Karang Taruna) Health Cadre (Kader Sehat) and representation of group of specific interest or activities, tourism care community (kelompok sadar wisata).

Community is also representing the specific product or characteristic of the village. As an example is the existence of Hindu priest as a representation of a village in Mambal Village on Badung Bali (arida et al.: 2017). The group of people such as pokdarwis (Tourism Care Community) has a responsibility in organizing the tourism village both for local people and tourist (Arida et al.:2017) (Widodo.s et al.:2018). Other groups function as a central attraction or specification of the village such as community of fish processing (widodo.s et al.:2018), coffee farmer community(maulana et al.:2018), forest farmer community (vitasurya:2016). Meanwhile, another group produces product and food as a souvenir such as handy craft home industry, culinary home industry. Cultural performance group will be responsible for art prevention and entertainment for the tourist (vitasurya; 2016).

More specifically, in the early planning of village tourism, the community becomes the core actor to establish this concept. As discussed by Amerta (2017) The role of the local community in the early planning of Jasri Tourism Village in Karang Asem, Bali comprises of (a) the commitment and the community support; (b) maintaining the cleanliness and the environment, (c) improving the quality of human resources; and (d) exploring the potential of local tourism. Meanwhile in the development stage community will work on (a) provide supporting tourism facilities; (b) establish supporting institutions of tourism; (c) introduce and publish Jasri tourism potential (Amerta: 2017).

Cultural group and senior farmers from the coffee farmer community (LMDH) / develop their communication objective as an international Coffee winner, Strengthen their culture as high solidarity and friendly village, maintain and promote their high-quality coffee grown that is using $100 \%$ organic fertilizer to produce Arabica coffee quality,(Maulana: 2018) 


\section{Government}

Government is the second important stakeholder in developing and managing the village tourism in a region. Most of the cases studied agree that government plays a significant role not only planning, controlling, evaluating but also promoting the village. In the case of village tourism program, local government is a determining factor in creating a development program and as the significant actor to implement and to monitor activities to achieve the goal (Maulana: 2018). The government involve ranging from the base element of government structure that is village administrative (Lurah), Regional Government shall be the Governor, the Regent, or Mayor and the official elements of the Regional Government and the highest position is minister shall be the Minister of Tourism, Minister of village, development, and transmigration, Minister of Women Empowerment.

The main function of governments is to regulate the relationships among members of a society and between the society and outsiders and that they have the authority to make decisions for the society to meet goals and maintain order. Furthermore the most important role of government toward the village tourism program is a regulatory function. The legitimization on tourism village through a letter of decree is important (amerta:2017) (widodo:2018). As an example in Sleman Yogyakarta, the support from regional government come from Cultural and Tourism Agency. The agency constructs a draft of a regulation that determined basic aspects of development and communication for the tourism village. In the draft there were four aspects that became the main focus of the regulation. They were destination development, industrial development in rural tourism area, tourism village marketing development, and institutional structure (Purnama, 2016). Focusing on the fourth aspect, the agency encouraged tourism villages to form legal entities such as cooperation. The reason was that many corporations and assistance in the tourism sector that required the recipient must be incorporated. Furthermore, this effort is made to encourage tourism village to be more professional. With this regulation, tourism village was directed to be well managed under the coordination of the Cultural and Tourism Agency of Sleman Yogyakarta (prayudi et al., 2017).

Funding is also the main issues that government involvement will matter for village tourism. Dominantly, funding is distributed by central government like the ministry of tourism with its National Community Empowerment Program (PNPM Mandiri). Through this program, the central government wants to involve and empower the community in rural development by rolling aid funds to villages in Indonesia(Amerta : 2017)

\section{Business}

Most of the finding shows the important role of tour and travel agencies to accommodate the tourists to the village. The engagement of Association of the Indonesian Tours and Travel Agencies will helps relating tourists' needs with village attraction. Beside that tour and travel agencies can be a mediator between markets with the village product. Another association that needs to be engaged is Association of Indonesian Hotels, especially four and five-star hotels that are located in nearby the village tourism. Hotel management can help management of 
ecotourism village on issues like expanding tourism marketing, improving human resource capacity, raising local potentials, and applying tourism business standards (Sukarmi, 2016). Another stakeholder found in the research is an investor and private company. Both of them believe to have a contribution to investing some capital as well as allocate its CSR budget

Furthermore, the investors or businessmen originally from Jasri Village have also played important role, such as (a) proposing the idea of tourism development in Pakraman Village of Jasri; (b) giving motivation; and (c) preparing accommodation; (d) to promote the Village Tourism of Jasri; and (e) providing feedback of innovative new tourist attractions.( (Amerta : 2017)

The involvements of these outsiders in a village have to be managed and control not only by the community but also the government to make the program in the right track. There must be a strong commitment to cooperate with local community, government and if necessary cooperate with other private parties. Think about and identify the impact if private parties are to be involved, in particular tour and travel agencies. These commitments can only be achieved if the new mindset has been formed (Parayudi et al 2017).

\section{Academic}

Academic is used to describe things that relate to the work done in schools, colleges, and universities, especially work which involves studying and reasoning rather than practical or technical skills. The finding shows that the academic role is not a lot to be discussed. Only one case in kedal describes its contribution that is mentoring household fish processing (Widodo:2018). The potential economic sector on Tanjungsari County of Rowosari District Kendal is Fish Processing Household. Most residents of Tanjungsari make a business on fish processing. This activity was supported by the government with the programs on household industry. The role of academic in this case, was the mentoring program of the household. This action was cooperation between of Semarang PGRI University with BAPEDA of Kendal District. Home industry is also expected to have a role in developing Tanjungsari County. The fish processing was set up as a tourist main attraction for educational tour program in Tanjungsari.

Social entrepreneur

Social entrepreneurship looks to create positive changes in the world predominantly. They must make a profit to do this - so they can spend those profits on charitable actions. Meanwhile business entrepreneur less focuses on specified social mission attached to their business. In this study, most of the case does not discuss the role of a social entrepreneur. One case on Lopati Village gave information about the existence of entrepreneur actors. There are 17 types of businesses with 47 entrepreneurs, and 34 persons who participated in providing homestays for tourists in Lopati Village. Most of these homestay owners have other business and only two of them do not have any business (vitasurya,2016). Based on the finding the entrepreneurs mention in that research is classified as a business entrepreneur. As a result, all of the research being studied there is no evident that the roles of social entrepreneurs exist in the village tourism. 


\section{Cross-sector collaboration}

Managing and developing village tourism is hard to establish by a single stakeholder. A partnership among other stakeholders et al. important to keep the village tourism program on the right track. Since the village has an authentic traditional experience, thus it needs to be developing carefully and preserve gradually. As a consequence, the cooperation among the community, government, business, academic and social entrepreneur or what is called Penta helix is important in developing and managing village tourism. Based on the study the model of Penta helix partnership is shown in the diagram below;

Figure 1: Penta Helix Model

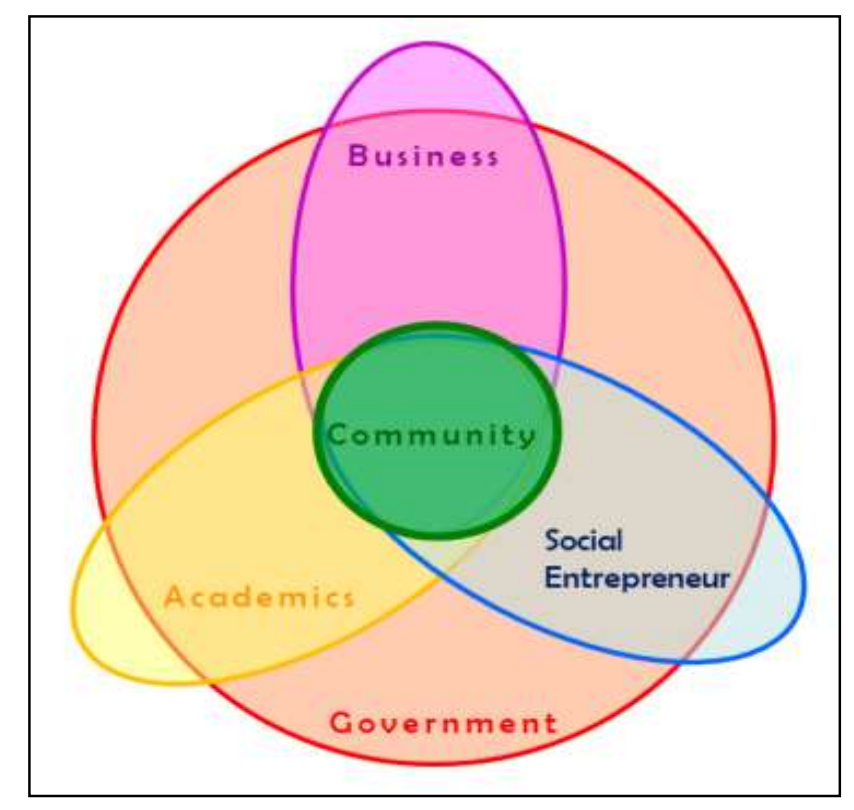

\section{CONCLUSION}

By assessing Penta Helix as cross-sector collaboration in the village tourism, the study provides a model of how Penta helix actors role in village tourism development and management. The central actor of the Penta helix model is a community who will manage the village with its characteristics. They will be responsible for the value of the village not only in the context of attraction but also the social and culture elements. The second core actor will be the government. As a policy maker, government has an authority to preserve and maintain the development of the tourism village. Beside provide some fund and assistance to the village, the government is also performing a function as facilitator and mediator to other three stakeholders in Penta helix they are; business, academics, and social entrepreneur. 


\section{REFERENCES}

Amerta, I. M. S. (2017). The Role of Tourism Stakeholders at Jasri Tourism Village Development, Karangasem Regency. International Journal of Social Sciences and Humanities (IJSSH), 1(2), 20-28.

Arida, Wiguna, I W Narka and N K O Febrianti.,(2017) Development Planning of Tourist Village Using Participatory Mapping (Case study: Mambal Village, Badung Regency, Indonesia): The $5^{\text {th }}$ Geoinformation Science Symposium, IOP Conference. Series: Earth and Environmental Science.

Badan Pusat Statistik (2017). Pengangguran Terbuka Menurut Pendidikan Tertinggi yang Ditamatkan 1986-2017. Tersedia di https://www.bps.go.id/linkTabelStatis/view/id/972, diakses pada Mei 2017

Björk, F., Hansson, J. and Lundborg, D. (2014). An Ecosystem for social innovation in Sweden: A strategic research and innovation agenda. Lund: Lund University.

Brooks, A. (2008) Social entrepreneurship: a modern approach to social value creation. (Upper Saddle River, NJ: Prentice-Hall).

Bryson, John M., Barbara C. Crosby, and Melissa Middleton Stone. (2006). "The Design and Implementation of Cross-Sector Collaborations: Propositions from the Literature." Public Administration Review 20: 45-55

Calzada, I. (2016). (Un) Plugging Smart Cities with urban transformations: towards multi-stakeholder city-regional complex urbanity? URBS, Revista de Estudios Urbanos y Ciencias

Detik.com. (2018) Desa Wisata yang Bisa Genjot Ekonomi Retrieved December 3, 2018, from https://finance.detik.com/berita-ekonomi-bisnis/d-4336859/ada1700-desa-wisata-yang-bisa-genjot-ekonomi-ri

Etzkowitz, H. (1998) The norms of entrepreneurial science - Cognitive effects of the new university-industry linkages. Research Policy, Vol. 1, No. 27, pp. 823833.

Gardiner, P,D (2005). Project Management-A Strategic Planning Approach. New York,USA: Palgrave Macmillan.

Gibson, K (2000). The moral basis of stakeholder theory. Journal of Business Ethics, 26(3):245

Gyrd-Jones R. and Kornum, N. (2013). Managing the co-created brand: Value and cultural complementarity in online and offline multi-stakeholder ecosystems. Journal of business research (66), 1484-1493.

Halibas, Sibayan, and Maata. (2017). The Penta Helix Model of innovation in Oman: An Hei Perspective. Interdisciplinary Journal of Information, Knowledge and Management 12, 159-174.

Inskeep, E. (1991). Tourism planning: an integrated and sustainable development approach. Van Nostrand Reinhold

Manente,M. Minghetti, V. (2006). Tourism Business Frontiers: consumers, products and industry - Destination management organizations and actors, Elsevier Butterworth-Heinemann, Oxford.

Maulana Yopy and M F Sitinjak (2018) IOP Conf. Ser.: Earth Environ. Sci. 126 012064

Mitchell, R., Agle, B., and Wood, D. (1997). Toward a theory of stakeholder identification and salience: Defining the principle of who and what really counts. The Academy of management review, 22(4), 853-886. 
Minister of Tourism number PM.26/UM.001/MKP/2010 on general guideline of national program on tourism human empowerment trough village tourism.

Muslim. A. (2016) Economic Community Empowerment Through Tourist Village Development MIMBAR, Vol. 32, No. 2nd, pp.343-352.343

Newcombe, R. (2003), "From client to project stakeholders: a stakeholder mapping approach", Construction Management and Economics, 21(8), 841-48.

Pandey, R.N., Chettri, P., Kunwar, R.R. and Ghimire, G. (1995). Case Study on Effect of Tourism on Culture and Environment, Nepal-Chitwan-Sauraha and Pokhara-Ghandruk, Bangkok: UNESCO Principal Regional Office for Asia and the Pacific.

Petrevska, B., \& Dimitrov, N. V. (2013). Planning rural tourism development in Macedonia. Journal of Process Management - New. Technologies, 1, 63 - 68.

Prayogi, P.A. (2011). Dampak Perkembangan Pariwisata Di Objek Wisata Penglipuran. Jurnal Perhotelan dan Pariwisata. Vol 1. No 1: 64-79.

Prayudi, Susilo., M .E.D.Y. and herastuti, H. (2017). Analyzing Challenges Of Developing Ecotourism Village In Sleman, Yogyakarta, Indonesia: A Community Development Approach. PEOPLE: International Journal of Social Sciences, 3(3), 510-526.

Suarthana, I Ketut Putra and Karta, Ni Luh Putu Agustini. (2013). Model Partisipasi Masyarakat Dan Dampak Sosial Ekonomi Desa Wisata Purbakala Bedulu, Gianyar Bali p 20. Proceeding Doctoral Colloquium and Conference "Ethically Sustainable Business Practice and Green Economy"Program Magister Sains dan Doktor FEB UGM

Thomson, Ann Marie, and James L. Perry. (2006). "Collaboration Processes: Inside the Black Box.” Public Administration Review 66: 20-32.

Waligo, V. M., Clarke, J. and Hawkins, R. (2013). Implementing sustainable tourism: A multi-stakeholder involvement management framework. Tourism management, (36), 342-353.

Widodo. S., Rosalina. G., Supriyono .P. S., and R. Istiyaningsih (2018) Community Participation in the Implementation of Constitutional Laws through the Village Tourism Development in Tanjungsari County Rowosari Subdistrict Kendal: Journal of Science Studies ISSN 2329-9150 Vol.5, No1. http://jsss.macrothink.org

Vitasurya.V.R.( 2016 ) Local Wisdom for Sustainable Development of Rural Tourism, Case on Kalibiru and Lopati Village, Province of Daerah Istimewa Yogyakarta: Social and Behavioral Sciences 21697 - 108. Published by Elsevier Ltd. 